\title{
Effect of additives on densification and deformation of tetragonal zirconia
}

\author{
M. M. R. BOUTZ, A. J. A. WINNUBST*, F. HARTGERS, A. J. BURGGRAAF \\ University of Twente, Faculty of Chemical Technology, Laboratory for Inorganic Chemistry, \\ Materials Science and Catalysis, P.O. Box 217, 7500 AE Enschede, The Netherlands
}

The effect of additives $\left(\mathrm{Bi}_{2} \mathrm{O}_{3}, \mathrm{Fe}_{2} \mathrm{O}_{3}\right)$ on densification and creep rates of tetragonal $\mathrm{ZrO}_{2}-\mathrm{Y}_{2} \mathrm{O}_{3}$ has been investigated. In $\mathrm{Bi}_{2} \mathrm{O}_{3}$-doped $\mathrm{Y}-\mathrm{TZP}$, a reactive liquid forms at temperatures above $800-900^{\circ} \mathrm{C}$, which leads to a strong enhancement of densification for concentrations of $1-2 \mathrm{~mol} \% \mathrm{Bi}_{2} \mathrm{O}_{3}$. However, during cooling from the processing temperature a strong, undesirable transformation of the tetragonal to the monoclinic phase occurs. The addition of $0.6-1.2 \mathrm{~mol}_{\%} \mathrm{FeO}_{3 / 2}$ promotes densification without destabilizing the tetragonal phase. A concentration of $1.2 \mathrm{~mol} \%$, however, induces discontinuous grain growth, while this is not the case for $0.6 \mathrm{~mol} \%$. Creep rates of Y-TZP were enhanced by a factor of $4-6$ by adding $0.6 \mathrm{~mol} \% \mathrm{FeO}_{3 / 2}$.

\section{Introduction}

Ceramic superplasticity was demonstrated for the first time in 1986 by Wakai et al. [1], who obtained a large $(170 \%)$ tensile strain at $1450^{\circ} \mathrm{C}$ using $3 \mathrm{~mol} \% \mathrm{Y}_{2} \mathrm{O}_{3}$ stabilized tetragonal zirconia polycrystals (3Y-TZP). Currently, elongations up to $800 \%$ have been obtained with this material [2]. Such large tensile ductilities offer the possibility to use superplastic forming (SPF) techniques for near-net shaping. Techniques such as extrusion [3, 4], bulging [5] and gas-pressure forming [6] have been successfully applied to both single-phase and composite ceramics. High strain rates at preferably low temperatures are prerequisites to make SPF of ceramics economically attractive.

Two main routes are available to increase strain rates and/or lower forming temperatures: (i) decreasing the grain size towards the nanometreregime (grain size below $100 \mathrm{~nm}$ ) and (ii) using additives, which lead to the formation of (eutectic) liquids at the SPF temperature. The first route can be accomplished by low-temperature sintering. For undoped systems this requires the synthesis of nanocrystalline powders composed of very soft agglomerates. Green bodies with high densities and small pore radii can be produced using such powders and this leads to good sinterability at very low temperatures, where grain growth is very slow $[7,8]$. In the second route, transition metal oxides of the fourth row, such as $\mathrm{MnO}$ [9] and $\mathrm{CuO}$ [10], are being used, which lead to the formation of eutectic liquids at low temperatures. These liquids are present as thin (1-2 nm) films on the grain boundaries and lead to a substantial enhancement of deformation rates.

After the forming operation it would be advantageous in the second route to remove the liquid-forming additive, because the presence of excess amorphous phases might deteriorate the room-temperature mechanical properties. For instance, under certain conditions the presence of an intergranular amorphous phase leads to an increased wear rate of TZP [11].

$\mathrm{Bi}_{2} \mathrm{O}_{3}$ could fulfil these requirements: it forms a reactive liquid at temperatures above $900^{\circ} \mathrm{C}$ and its volatility can be used to remove it by a post-forming annealing treatment. However, it has been reported by Burggraaf and co-workers $[12,13]$, that in the case of cubic $\mathrm{ZrO}_{2}-\mathrm{Y}_{2} \mathrm{O}_{3}$, substantial amounts of the monoclinic phase form when using $\mathrm{Bi}_{2} \mathrm{O}_{3}$ as a sintering additive. If a similar degree of transformation would take place in tetragonal $\mathrm{ZrO}_{2}-\mathrm{Y}_{2} \mathrm{O}_{3}$, this would considerably decrease the extent to which transformation toughening [14] can operate and is therefore quite undesirable. The suitability of $\mathrm{Bi}_{2} \mathrm{O}_{3}$ as a sintering aid to produce dense, fine-grained, fully tetragonal zirconia will therefore be evaluated here in the first place. Special attention has been paid to the influence of $\mathrm{Bi}_{2} \mathrm{O}_{3}$-concentration, stabilizer type (yttrium, cerium) and different sintering schedules, on the phase content.

$\mathrm{Fe}_{2} \mathrm{O}_{3}$ is possibly another suitable candidate to enhance strain rates without introducing excess amorphous phase. Chen and Xue [15] demonstrated, in a survey of the effect of transition metals, that the addition of iron oxide enhances deformation rates of Y-TZP. It is also well known that $\mathrm{Fe}_{2} \mathrm{O}_{3}$ forms a solid solution with $\mathrm{ZrO}_{2}$ at elevated temperatures $[13,16]$. Verkerk et al. $[13,16]$ have observed that the addition of $0.5-2 \mathrm{~mol} \% \quad \mathrm{Fe}_{2} \mathrm{O}_{3}$ leads to a significant enhancement of densification of cubic $\mathrm{ZrO}_{2}-\mathrm{Y}_{2} \mathrm{O}_{3}$. The capability of $\mathrm{Fe}_{2} \mathrm{O}_{3}$ as a solid solution additive to enhance sintering and deformation rates of Y-TZP was investigated in the present work. 


\section{Experimental procedure}

\subsection{Powder synthesis and dispersion of additives}

Zirconia powders with either 5 at $\%$ yttrium (denoted ZY5) or 12 at \% cerium (denoted ZCe12) have been synthesized by a gel-precipitation technique using metal chlorides as precursor chemicals. This technique is commonly referred to as the "chloride" method and is described in more detail elsewhere [17-19]. Three different $Z Y 5$ batches were used in this investigation: they are denoted $Z Y 5(x)$, where $x$ equals 1,2 or 3 . Batches ZY5(1) and $Z \mathrm{Ce} 12$ were used for $\mathrm{Bi}_{2} \mathrm{O}_{3}$ doping, while the other two batches were used for $\mathrm{Fe}_{2} \mathrm{O}_{3}$ doping. Calcination took place at $500-550^{\circ} \mathrm{C}(2 \mathrm{~h})$ in static air.

$\mathrm{Bi}_{2} \mathrm{O}_{3}$ (Merck, reinst) was introduced mainly by dry milling in this investigation. Zirconia powders were mixed with $\mathrm{Bi}_{2} \mathrm{O}_{3}$ powder in polyethylene flasks with PTFE (polytetrafluorethylene, teflon) marbles and put on a rolling bench during the night. The hard zirconia powder thus acts as a grinding medium for the much softer $\mathrm{Bi}_{2} \mathrm{O}_{3}$ powder. Concentrations of $\mathrm{Bi}_{2} \mathrm{O}_{3}$ ranged from $0.15-2.0 \mathrm{~mol} \%$ for doping of ZY5 and a concentration of $2 \mathrm{~mol} \%$ was used for doping of ZCe12. The lowest dopant level of $\mathrm{Bi}_{2} \mathrm{O}_{3}(0.15 \mathrm{~mol} \%)$ was also introduced by wet impregnation using solutions of $\mathrm{Bi}\left(\mathrm{NO}_{3}\right)_{3}$ in nitric acid.

$\mathrm{Fe}_{2} \mathrm{O}_{3}$ was introduced to calcined $\mathrm{ZY} 5$ powders by a chemisorption technique using ironacetylacetonate $\left(\mathrm{FeC}_{15} \mathrm{H}_{21} \mathrm{O}_{6}\right.$, abbreviated to $\mathrm{Fe}(\mathrm{AcAc})_{3}$, Merck, $>98 \%$ pure). A certain amount ( $10 \mathrm{~g})$ of powder was mixed by gentle stirring with a 11 solution of $\mathrm{Fe}(\mathrm{AcAc})_{3}\left(7 \mathrm{gl}^{-1}\right)$ in ethanol for 2-72 $\mathrm{h}$. The maximum solubility of $\mathrm{Fe}(\mathrm{AcAc})_{3}$ in ethanol at $20^{\circ} \mathrm{C}$ was determined to be $25 \mathrm{gl}^{-1}$. The doped powder was retrieved by filtration, thoroughly washed with ethanol to remove non-adsorbed $\mathrm{Fe}(\mathrm{AcAc})_{3}$, dried at $120^{\circ} \mathrm{C}$ and finally calcined at $450^{\circ} \mathrm{C}$ for $30 \mathrm{~min}$. This chemisorption technique will be referred to below as the batch-acetylacetonate method [20]. The characteristics of $\mathrm{ZY} 5$ powders doped with 0.6 and $1.2 \mathrm{~mol}^{\%} \mathrm{FeO}_{1.5}$ were investigated.

\subsection{Green compact formation and sintering}

Green compacts were produced by cold isostatic compaction in two steps: first at $80-100 \mathrm{MPa}$ and finally at $400 \mathrm{MPa}$. Free sintering behaviour was analysed in detail by dilatometry using a Netzsch 402 E dilatometer. Densities calculated from the green density and the observed linear shrinkage, corrected for weight loss and thermal expansion, were in good agreement with those measured by the Archimedes' technique. During non-isothermal experiments, samples were heated at $2^{\circ} \mathrm{C} \mathrm{min}^{-1}$ to $1460^{\circ} \mathrm{C}$, immediately followed by cooling down at $4^{\circ} \mathrm{C} \mathrm{min}{ }^{-1}$ to room temperature. Isothermal experiments (heating rate $2^{\circ} \mathrm{Cmin}^{-1}$, cooling rate $4^{\circ} \mathrm{C} \mathrm{min}^{-1}$ ) were performed at $1050^{\circ} \mathrm{C}$ (10 h) with $\mathrm{Bi}_{2} \mathrm{O}_{3}$-doped $\mathrm{ZY} 5$, at $950-1000^{\circ} \mathrm{C}(5-15 \mathrm{~h})$ with $\mathrm{Bi}_{2} \mathrm{O}_{3}$ doped $\mathrm{ZCe} 12$ and at $1050-1110^{\circ} \mathrm{C}(15 \mathrm{~h})$ with $\mathrm{Fe}_{2} \mathrm{O}_{3}$-doped $\mathrm{ZY} 5$.

Separate sintering experiments were performed in a furnace at $675-1100^{\circ} \mathrm{C}(1 \mathrm{~h})$ with $2 \mathrm{~mol} \% \mathrm{Bi}_{2} \mathrm{O}_{3}$ - doped ZY5 or in a tube furnace at $1150-1400^{\circ} \mathrm{C}$ for ZY5 doped with $0.6-1.2 \mathrm{~mol} \% \mathrm{FeO}_{1.5}$.

\subsection{Characterization techniques}

Nitrogen adsorption/desorption isotherms were obtained at $77 \mathrm{~K}$ using a Micromeritics ASAP 2400 system. Specific surface areas were analysed by the BET method. No corrections for microporosity were necessary. Stabilizer (yttrium, cerium) content was measured by XRF using a Philips PW1410 spectrometer. Dopant (iron, bismuth) concentrations after wet impregnation/chemisorption were determined by AAS. Powders were dissolved in concentrated sulphuric acid for AAS analyses. Bulk densities were determined by the Archimedes' technique (in mercury).

The phase composition was analysed by XRD using a Philips PW1370 diffractometer with $\mathrm{Cu} K_{\alpha}$-radiation. The volume fraction of the monoclinic phase, $V_{\mathrm{m}}$, was estimated using the non-linear relationship proposed by Toraya et al. [21]. Unit-cell dimensions were determined by precision X-ray measurements using silicon as an internal standard.

Grain sizes were determined by the lineal intercept technique from scanning electron micrographs (Hitachi S800 or Jeol JSM-35CF) of polished, thermally etched cuts using $D=1.56 L$, where $L$ is the average lineal intercept.

\subsection{High-temperature compression}

Compression tests were performed in air under constant load on cylindrical samples (height $13 \mathrm{~mm}$, diameter $5 \mathrm{~mm}$ ) using an Elatec hydraulic compression machine equipped with $\mathrm{SiC}$ pistons. Axial displacements were measured internally. More details concerning the configuration of this equipment are given elsewhere [22]. Samples were heated at $20^{\circ} \mathrm{C} \mathrm{min}^{-1}$ to the desired temperature $\left(1200-1300^{\circ} \mathrm{C}\right)$, equilibrated for $15 \mathrm{~min}$ and compressed to $0.4-0.5$ true strain. During heating and temperature equilibration, no load was applied to the specimens. Sapphire discs were used to avoid direct contact between sample and pistons. Samples of ZY5(2) undoped and doped with $0.5 \mathrm{~mol} \% \mathrm{FeO} 1.5$ used for compression tests were sintered at $1150^{\circ} \mathrm{C}(15 \mathrm{~h})$ to $96 \%-97 \%$ relative density.

\section{Results}

\subsection{Undoped powder characteristics}

The chemical composition and specific surface areas of the synthesized powders are given in Table I. The actual chemical composition is close to the desired composition for all powders. Specific surface areas range from $96-122 \mathrm{~m}^{2} \mathrm{~g}^{-1}$ for the three investigated ZY5 batches and $82 \mathrm{~m}^{2} \mathrm{~g}^{-1}$ is found for ZCe12. The crystallite size is $7-8 \mathrm{~nm}$ for all three investigated $\mathrm{ZY} 5$ batches and the variation in specific surface area is thus caused by a variation in the degree of aggregation. The lower specific surface area of ZCe12 compared to the ZY5 powders is primarily due to the 
TABLE I Chemical composition and specific surface areas of synthesized powders

\begin{tabular}{lll}
\hline $\begin{array}{l}\text { Powder } \\
\text { batch code }\end{array}$ & Composition & $\begin{array}{l}S_{\mathrm{BET}} \\
\left(\mathrm{m}^{2} \mathrm{~g}^{-1}\right)\end{array}$ \\
\hline $\mathrm{ZY5}(1)$ & $\mathrm{ZY5} 5.2$ & 122 \\
$\mathrm{ZY5}(2)$ & $\mathrm{ZY5} .0$ & 109 \\
$\mathrm{ZY5}(3)$ & $\mathrm{ZY} 5.2$ & 96 \\
$\mathrm{ZCe} 12$ & $\mathrm{ZCe} 11.8$ & 82 \\
\hline
\end{tabular}

larger crystallite size $(\sim 10 \mathrm{~nm})$. Densities near $95 \%$ could be obtained during free sintering at $1150^{\circ} \mathrm{C}$ $(10 \mathrm{~h})$ with all investigated powders without sintering aids.

\section{2. $\mathrm{Bi}_{2} \mathrm{O}_{3}$-doped TZP}

\subsubsection{Non-isothermal sintering}

Fig. 1 shows the relative shrinkages as a function of temperature for undoped $\mathrm{ZY} 5$ and for $\mathrm{Bi}_{2} \mathrm{O}_{3}$ dopant levels of $0.15,1$ and $2 \mathrm{~mol} \%$. The characteristic temperatures and maximum shrinkage rates, $[\mathrm{d} L /(L \mathrm{~d} t)]_{\mathrm{max}}$, can be found in Table II. From this table and Fig. 1 one can see that the onset of sintering, $T_{\text {onset }}$, is delayed by introducing $\mathrm{Bi}_{2} \mathrm{O}_{3}$ : in undoped ZY5, densification starts at $685^{\circ} \mathrm{C}$, while this temperature shifts to $970^{\circ} \mathrm{C}$ after the addition of $0.15 \mathrm{~mol} \%$. At higher dopant concentrations, the value of $T_{\text {onset }}$ decreases again, but is still equal to $880^{\circ} \mathrm{C}$ for $2 \mathrm{~mol} \%$. Once densification starts it proceeds at a much higher rate in the $\mathrm{Bi}_{2} \mathrm{O}_{3}$-doped materials. Densification is completed within a temperature interval (given by $T_{\text {end }}-T_{\text {onset }}$ ), where $T_{\text {end }}$ is the temperature

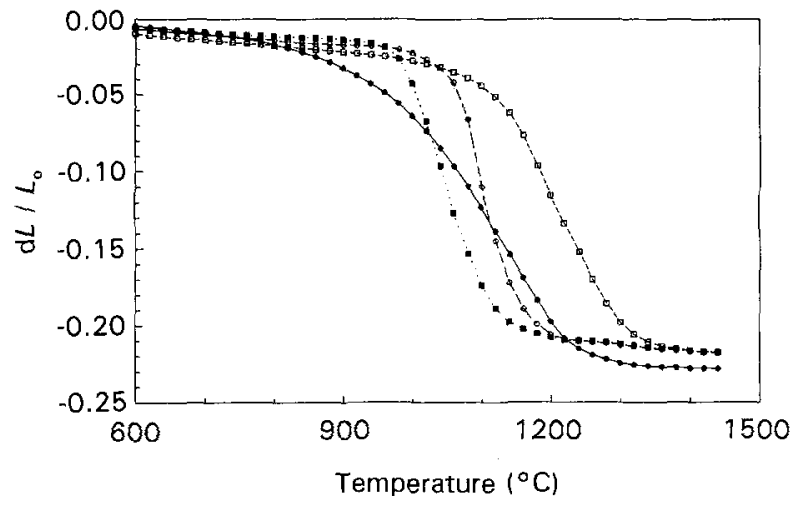

Figure 1 Relative shrinkage versus temperature during heating at $2{ }^{\circ} \mathrm{C} \mathrm{min}^{-1}$ of pure and $\mathrm{Bi}_{2} \mathrm{O}_{3}$-doped $\mathrm{ZY} 5(1)$. Dopant levels (mol \% $\left.\mathrm{Bi}_{2} \mathrm{O}_{3}\right):(\bigcirc) 0,(\square) 0.15,(\bigcirc) 1,(\boldsymbol{\square}) 2$.

TABLE II Characteristic data of non-isothermal sintering of pure and $\mathrm{Bi}_{2} \mathrm{O}_{3}$-doped $\mathrm{ZY} 5(1)$

\begin{tabular}{llllll}
\hline $\begin{array}{l}\mathrm{Bi}_{2} \mathrm{O}_{3} \\
(\mathrm{~mol} \%)\end{array}$ & $\begin{array}{l}T_{\text {onset }} \\
\left({ }^{\circ} \mathrm{C}\right)\end{array}$ & $\begin{array}{c}T_{\text {end }} \\
\left({ }^{\circ} \mathrm{C}\right)\end{array}$ & $\begin{array}{c}T_{\max } \\
\left({ }^{\circ} \mathrm{C}\right)\end{array}$ & $\begin{array}{l}M_{\mathrm{s}} \\
\left({ }^{\circ} \mathrm{C}\right)\end{array}$ & $\begin{array}{c}-(\mathrm{d} L / L \mathrm{~d} t)_{\max } \\
\left(10^{-4} \mathrm{~min}^{-1}\right)\end{array}$ \\
\hline 0 & 685 & 1320 & 1115 & $<20$ & 8 \\
0.15 & 970 & 1385 & 1175 & $<20$ & 19 \\
1.0 & 960 & 1240 & 1090 & 463 & 44 \\
1.5 & 920 & 1220 & 1055 & 461 & 30 \\
2.0 & 880 & 1215 & 1035 & 517 & 27 \\
\hline
\end{tabular}

at which densification ends) of $635^{\circ} \mathrm{C}$ for undoped ZY5, whereas for $\mathrm{Bi}_{2} \mathrm{O}_{3}$ concentrations of $1-2 \mathrm{~mol} \%$ this interval narrows considerably to $280-335^{\circ} \mathrm{C}$. It can also be seen in Table II that the temperature at which the shrinkage rate is maximal, $T_{\max }$, shifts from $1115^{\circ} \mathrm{C}$ for undoped $\mathrm{ZY} 5$ to $1035^{\circ} \mathrm{C}$ for $2 \mathrm{~mol} \%$ $\mathrm{Bi}_{2} \mathrm{O}_{3}$-doped $\mathrm{ZY} 5$. The maximum shrinkage rates of $\mathrm{Bi}_{2} \mathrm{O}_{3}$-doped materials are increased by a factor of 2.4-5.5 compared to undoped ZY5. All samples reach 96\%-99\% relative density at $T_{\text {end }}$.

For concentrations of 1-2 mol \%, a considerable improvement of the sintering kinetics is observed (see Fig. 1). However, these concentrations lead to a strong destabilization of the tetragonal phase, as evinced by a sudden expansion of the samples during cooling caused by the transformation "burst" to the monoclinic phase (see Fig. 2). This allowed the determination of the $M_{\mathrm{s}}$ temperatures as listed in Table II: $M_{\mathrm{s}}$ increases from $460^{\circ} \mathrm{C}$ at $1.0-1.5 \mathrm{~mol} \% \mathrm{Bi}_{2} \mathrm{O}_{3}$ to $520^{\circ} \mathrm{C}$ at $2 \mathrm{~mol} \% \mathrm{Bi}_{2} \mathrm{O}_{3}$. XRD showed that the monoclinic volume content equals approximately $65 \%$ in these materials.

Small additions of $\mathrm{Bi}_{2} \mathrm{O}_{3}(0.15 \mathrm{~mol} \%)$ retard the densification of $\mathrm{Y}$-TZP to such an extent that it gives no effective improvement of the sintering behaviour. The sintering behaviour of $0.15 \mathrm{~mol} \% \mathrm{Bi}_{2} \mathrm{O}_{3}$-doped (added by dry milling) ZY5 could possibly be improved by a better degree of dispersion. Therefore, $0.2 \mathrm{~mol} \% \mathrm{Bi}_{2} \mathrm{O}_{3}$ was added by wet impregnation. No improvement was found, however; the shrinkage versus temperature curve was quite similar to that of the material doped with $0.15 \mathrm{~mol} \% \mathrm{Bi}_{2} \mathrm{O}_{3}$ added by dry milling. No $M_{\mathrm{s}}$ temperature was observed during cooling of the $0.15-0.2 \mathrm{~mol} \% \mathrm{Bi}_{2} \mathrm{O}_{3}$ samples.

The characteristics of sintering ZCe12 with $2 \mathrm{~mol} \%$ $\mathrm{Bi}_{2} \mathrm{O}_{3}$ were also determined. This allows one to determine if the strong destabilization of the $\mathrm{t}$-phase as observed for the $\mathrm{Y}-\mathrm{TZP} / \mathrm{Bi}_{2} \mathrm{O}_{3}$ system also takes place for other rare-earth stabilizers. The relative shrinkages during heating to $1460^{\circ} \mathrm{C}$ of $\mathrm{ZCe} 12$ undoped and doped with $2 \mathrm{~mol} \% \mathrm{Bi}_{2} \mathrm{O}_{3}$ are shown in Fig. 3. The effect of $\mathrm{Bi}_{2} \mathrm{O}_{3}$ on densification of $\mathrm{ZCe} 12$ is, for the largest part, similar to the effect on ZY5. Densification

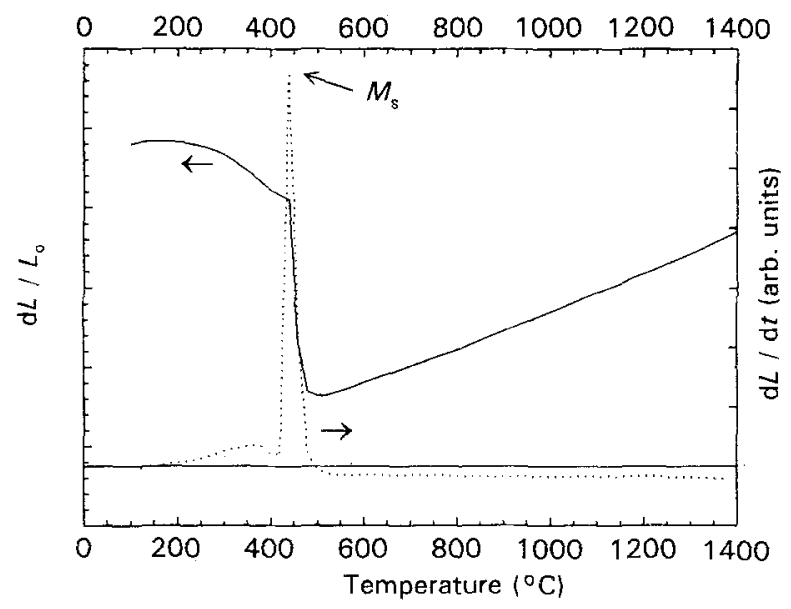

Figure 2 Example of the cooling part of a dilatometer curve obtained with $\mathrm{Bi}_{2} \mathrm{O}_{3}$-doped $\mathrm{ZY} 5$. The sudden expansion of the sample allows the determination of the $M_{\mathrm{s}}$ temperature. 


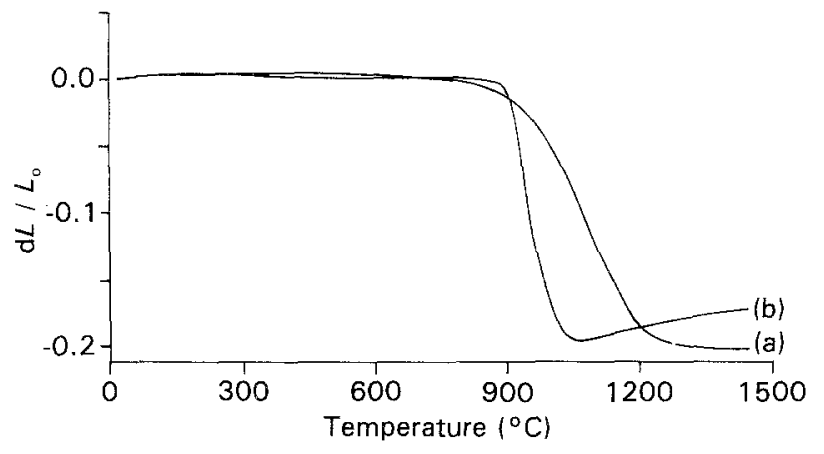

Figure 3 Relative shrinkage versus temperature during heating at $2 \mathrm{C} \mathrm{min}^{-1}$ of (a) pure and (b) $2 \mathrm{~mol} \% \mathrm{Bi}_{2} \mathrm{O}_{3}$-doped $\mathrm{ZCe} 12$.

is first delayed at $90^{\circ} \mathrm{C}$, but above $840^{\circ} \mathrm{C}$ it proceeds at a much faster rate in the doped material. The shift of $T_{\max }$ is rather large: it decreases from $1071^{\circ} \mathrm{C}$ to $941^{\circ} \mathrm{C}$. Compared to the $\mathrm{ZY} 5 / \mathrm{Bi}_{2} \mathrm{O}_{3}$ system, the initial delay is less and the shift of the shrinkage curve towards lower temperatures is larger for $\mathrm{ZCe} 12 / \mathrm{Bi}_{2} \mathrm{O}_{3}$ : Remarkably, the $2 \mathrm{~mol} \% \mathrm{Bi}_{2} \mathrm{O}_{3}$ doped material begins to swell above $1070^{\circ} \mathrm{C}$ : at $1460^{\circ} \mathrm{C}$ a total linear swelling of $1.95 \%$ (corrected for thermal expansion) is observed. The final density is only $81 \%$ of the theoretical one at this temperature.

The most important observation comes from the cooling curve of the $2 \mathrm{~mol} \% \mathrm{Bi}_{2} \mathrm{O}_{3}$-doped $\mathrm{ZCe} 12$ material heated to $1460^{\circ} \mathrm{C}$, where no $M_{\mathrm{s}}$ temperature could be observed. This indicates that the t-phase has not become unstable during this sintering schedule. XRD analysis confirmed that the material is $100 \%$ tetragonal. Swelling of the $2 \mathrm{~mol} \% \mathrm{Bi}_{2} \mathrm{O}_{3}$-doped ZCe12 material could be avoided by heating only to $1110^{\circ} \mathrm{C}$ (and immediately cooling). However, this led to destabilization of the t-phase as evinced by an $M_{\mathrm{s}}$ transition observed at $156^{\circ} \mathrm{C}$.

\subsubsection{Isothermal sintering}

Relative shrinkages as a function of time at $1050^{\circ} \mathrm{C}$ are shown in Fig. 4 for ZY5 undoped and doped with $1-2 \mathrm{~mol} \% \mathrm{Bi}_{2} \mathrm{O}_{3}$. The undoped material reaches only $72 \%$ theoretical density after $10 \mathrm{~h}$, while the $\mathrm{Bi}_{2} \mathrm{O}_{3}$ doped materials reach relative densities above $90 \%$. The cooling curves of the $\mathrm{Bi}_{2} \mathrm{O}_{3}$-doped materials sintered at $1050{ }^{\circ} \mathrm{C}$ showed no $M_{\mathrm{s}}$ temperatures, like those found after non-isothermal sintering. However, XRD analysis showed that $80 \%$ of the t-phase had transformed to the monoclinic one after this sintering schedule. Furthermore, diffraction peaks of an unidentified phase were detected in the $\mathrm{Bi}_{2} \mathrm{O}_{3}$-doped materials.

The drastic change of the microstructure of Y-TZP caused by the addition of $\mathrm{Bi}_{2} \mathrm{O}_{3}$ can be seen in the micrographs of Fig. $5 \mathrm{a}$ and b. Fig. $5 \mathrm{a}$ shows the microstructure of undoped ZY5, consisting of equiaxed grains of the $\mathrm{t}$-phase. Fig. $5 \mathrm{~b}$ shows the microstructure of $1.5 \mathrm{~mol} \% \mathrm{Bi}_{2} \mathrm{O}_{3}$-doped $\mathrm{ZY} 5$ after sintering at $1100^{\circ} \mathrm{C}$. Elongated and plate-like grains are observed of the monoclinic phase $\left(V_{\mathrm{m}}=80 \%\right)$. This observation is in agreement with the findings of Winnubst et al. [23], who observed elongated monoclinic grains in $2.3 \mathrm{~mol} \% \mathrm{Bi}_{2} \mathrm{O}_{3}$-doped cubic ZY17.

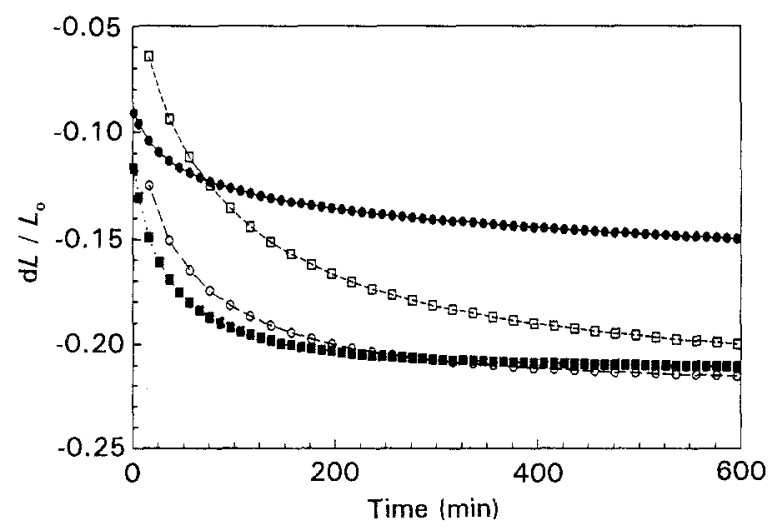

Figure 4 Relative shrinkage as a function of time during isothermal sintering at $1050^{\circ} \mathrm{C}$ of pure and $\mathrm{Bi}_{2} \mathrm{O}_{3}$-doped $\mathrm{ZY} 5$ (1). Dopant levels

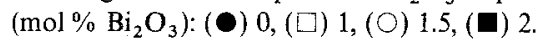

The $0.15 \mathrm{~mol} \% \mathrm{Bi}_{2} \mathrm{O}_{3}$-doped $\mathrm{ZY} 5$ was sintered at 1150 and $1200^{\circ} \mathrm{C}(10 \mathrm{~h})$, resulting in relative densities of only $61 \%$ and $70 \%$, respectively. Although such small concentrations have been found not to destabilize the t-phase, they do lead to a severe decrease of the sinterability of Y-TZP.

Isothermal sintering experiments were performed at $950-1000^{\circ} \mathrm{C}$ with $2 \mathrm{~mol} \% \mathrm{Bi}_{2} \mathrm{O}_{3}$-doped $\mathrm{ZCe} 12$. At $1000{ }^{\circ} \mathrm{C}$, a relative density of $95 \%$ was obtained after $50 \mathrm{~min}$. No $M_{\mathrm{s}}$ temperatures were observed in the cooling parts of these dilatometer runs, but again XRD analysis showed that most of the $t$-phase $(>90 \%$ ) had transformed to the monoclinic one. An unidentified phase was also detected after isothermal sintering.

\section{3. $\mathrm{Fe}_{2} \mathrm{O}_{3}$-doped $\mathrm{Y}$-TZP \\ 3.3.1. Chemisorption of $\mathrm{Fe}(\mathrm{ACAC})_{3}$ on tetragonal zirconia}

In order to be able to dope zirconia powders with a well-defined amount of $\mathrm{Fe}_{2} \mathrm{O}_{3}$ via the batch-acetylacetonate method, the adsorption kinetics of $\mathrm{Fe}(\mathrm{AcAc})_{3}$ on to the zirconia powder surface were determined first. The increase in iron-concentration with time at $20^{\circ} \mathrm{C}$ of batch ZY5(3) is shown in Fig. 6. The adsorption of $\mathrm{Fe}(\mathrm{AcAc})_{3}$ on zirconia from ethanol at $20^{\circ} \mathrm{C}$ is very slow: after $24 \mathrm{~h}$ a concentration of $0.55 \mathrm{~mol} \%$ $\mathrm{FeO}_{1.5}$ (equivalent to $0.05 \mathrm{~m} \mathrm{~mol} \mathrm{~m}^{-2}$ ) is reached. To obtain a concentration of $1.2 \mathrm{~mol}_{\%} \mathrm{FeO}_{1.5}$ requires $72 \mathrm{~h}$ adsorption time. In terms of monolayer coverages, $15 \%$ of a monolayer is covered after $24 \mathrm{~h}$ and $34 \%$ after $72 \mathrm{~h}$ by $\mathrm{Fe}(\mathrm{AcAc})_{3}$, assuming the area occupied by one $\mathrm{Fe}(\mathrm{AcAc})_{3}$ molecule equals $0.5 \mathrm{~nm}^{2}$ [24]. The adsorption mechanism of acetylacetonates on to oxide surfaces and ways to increase the monolayer coverages of $\mathrm{Fe}(\mathrm{AcAc})_{3}$ on zirconia surfaces will be discussed in Section 4.2.

\subsubsection{Solid solution formation}

The solubility of iron in tetragonal $\mathrm{ZrO}_{2}$ is equal to $3 \mathrm{~mol} \%$ as stated by Kiminami [16] (no experimental details were given by this author); Hughes and Badwal [25] showed that iron is distributed homogeneously 

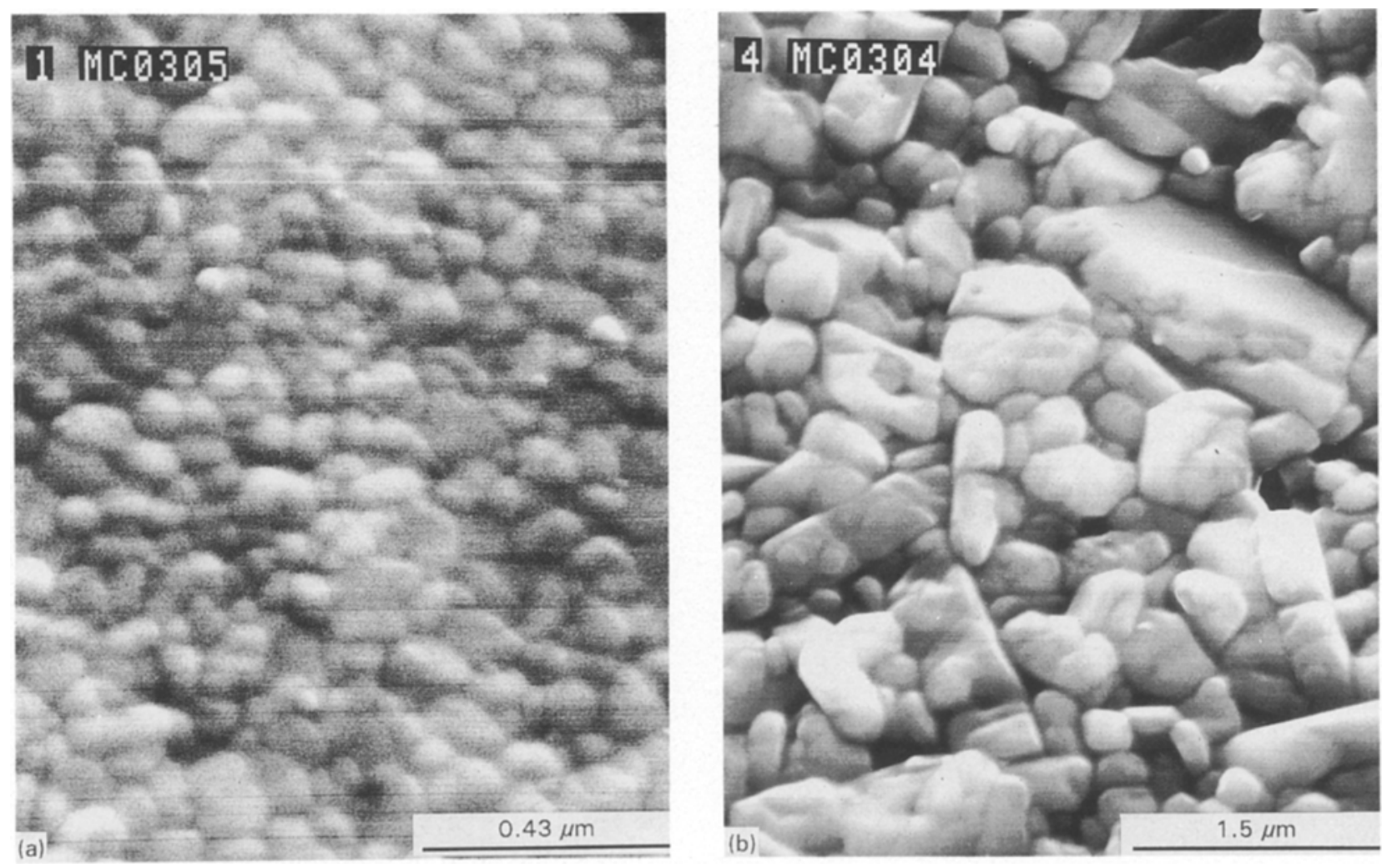

Figure 5 Microstructure after sintering at $1100{ }^{\circ} \mathrm{C}$ of (a) pure $\mathrm{ZY} 5(1)$ and (b) $1.5 \mathrm{~mol} \% \mathrm{Bi}_{2} \mathrm{O}_{3}$-doped $\mathrm{ZY} 5(1)$.

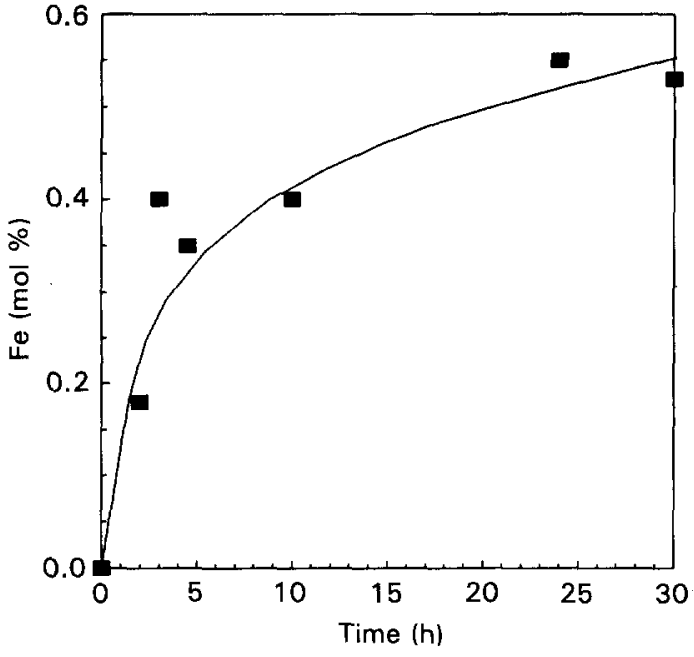

Figure 6 Increase with time of the adsorbed amount of iron on to ZY5(3) at $20^{\circ} \mathrm{C}$.

within Y-TZP grains after annealing at $1200^{\circ} \mathrm{C}$. In order to identify the mechanism of solid solution formation of $\mathrm{Fe}_{2} \mathrm{O}_{3}$ with tetragonal $\mathrm{ZrO}_{2}-\mathrm{Y}_{2} \mathrm{O}_{3}$ and to determine theoretical densities, lattice parameters were determined of ZY5(3) samples doped with $0,0.6$ and $1.2 \mathrm{~mol} \% \mathrm{FeO}_{1.5}$. Samples were heat treated at $1200^{\circ} \mathrm{C}(5 \mathrm{~h})$ after sintering to full density at $1150^{\circ} \mathrm{C}(10 \mathrm{~h})$ in order to diminish crystallite size broadening and promote dissolution of iron. The cooling rate was $240^{\circ} \mathrm{C} \mathrm{h}^{-1}$. Lattice parameters, unitcell volumes and theoretical densities of ZY5 doped with 0 and $0.6 \mathrm{~mol}^{\%} \mathrm{FeO}_{1.5}$ are given in Table III. Lattice parameters of $1.2 \mathrm{~mol} \% \mathrm{FeO}_{1.5}$-doped ZY5 could not be determined with acceptable accuracy,
TABLE III Unit-cell data of pure and $0.6 \mathrm{~mol}^{\%} \mathrm{FeO}_{1.5}$-doped ZY5

\begin{tabular}{lcccl}
\hline Composition & $a(\mathrm{~nm})$ & $c(\mathrm{~nm})$ & $V\left(\mathrm{~nm}^{3}\right)$ & $\begin{array}{l}\rho_{\mathrm{th}} \\
\left(\mathrm{g} \mathrm{cm}^{-3}\right)\end{array}$ \\
\hline ZY5 & 0.50995 & 0.51771 & 0.13463176 .06 \\
ZY5-0.6 Fe & 0.51050 & 0.51793 & 0.1349779 & 6.05 \\
\hline
\end{tabular}

because of poor peak resolution caused by broadening. It can be seen in Table III, that the unit-cell volume increases slightly by incorporation of $0.6 \mathrm{~mol} \% \mathrm{Fe}^{3+}$. On the basis of the unit-cell volumes given in Table III, the theoretical density of $1.2 \mathrm{~mol} \%$ $\mathrm{FeO}_{1.5}$-doped $\mathrm{ZY5}$ was calculated to be equal to $6.02 \mathrm{~g} \mathrm{~cm}^{-3}$ assuming (i) Vegard's law $\left(\Delta V / V_{0}=\alpha C\right.$, where $V_{0}$ is the volume of undoped ZY $C, C$ is the mole fraction of solute, i.e. $\mathrm{FeO}_{1.5}$ here, and $\alpha$ is Vegard's slope) holds, and (ii) all the iron has dissolved.

\subsubsection{Sintering and grain growth of $\mathrm{Fe}_{2} \mathrm{O}_{3}$-doped $\mathrm{Y}$-TZP}

The relative shrinkages during non-isothermal sintering of ZY5(3) doped with $0,0.6$ and $1.2 \mathrm{~mol} \%$ $\mathrm{FeO}_{1.5}$ are shown in Fig. 7 as a function of temperature. Green densities of undoped and $\mathrm{Fe}_{2} \mathrm{O}_{3}$-doped ZY5 were all equal to $45 \%$. With increasing iron concentration, the shrinkage curves are seen progressively to displace towards lower temperatures. The temperature at which the maximum shrinkage rate is observed, is lowered by $100^{\circ} \mathrm{C}$ upon addition of $1.2 \mathrm{~mol}_{\%} \mathrm{FeO}_{1.5}$ compared to undoped ZY5. All 


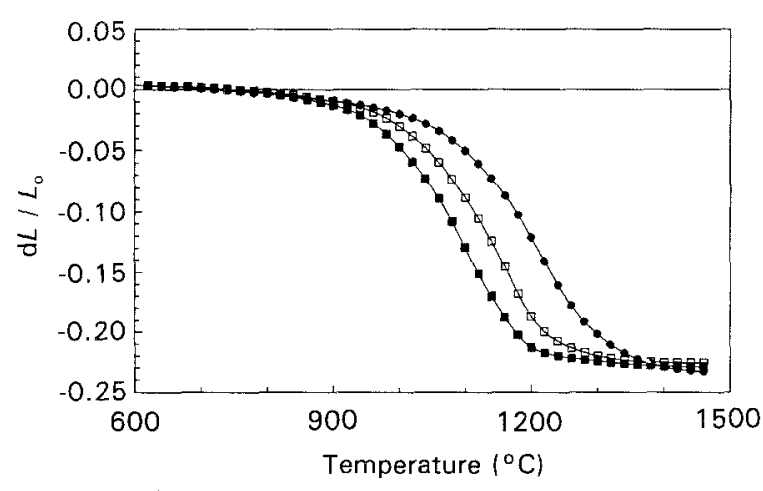

Figure 7 Relative shrinkage versus temperature during non-isothermal sintering of $(\bullet)$ pure and iron-doped $\mathrm{ZY} 5(3)$. Investigated

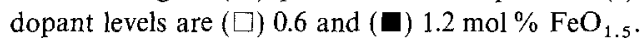

three materials are $>95 \%$ dense after non-isothermal sintering.

Relative shrinkages during isothermal sintering at $1160{ }^{\circ} \mathrm{C}$ are shown as a function of time in Fig. 8 for ZY5(3) doped with $0-1.2 \mathrm{~mol} \% \mathrm{FeO}_{1.5}$. The sintering time is reduced from $>10 \mathrm{~h}$ for undoped $\mathrm{Y}$ $\operatorname{TZP}\left(\rho_{\text {final }}=93 \%\right)$ to less than $5 \mathrm{~h}$ for $0.6-1.2 \mathrm{~mol} \%$ $\mathrm{FeO}_{1.5}$ doped Y-TZP $\left(\rho_{\text {final }}=95 \%\right)$.

Grain sizes after non-isothermal sintering and isothermal sintering at $1160^{\circ} \mathrm{C}$ are given in Table IV for all three investigated ZY5(3) materials. It can be concluded from these data that the addition of $0.6 \mathrm{~mol} \% \mathrm{FeO}_{1.5}$ does not affect grain growth in $\mathrm{ZY} 5$, while a concentration of $1.2 \mathrm{~mol} \%$ strongly promotes grain growth at $1160^{\circ} \mathrm{C}$. The microstructure of the

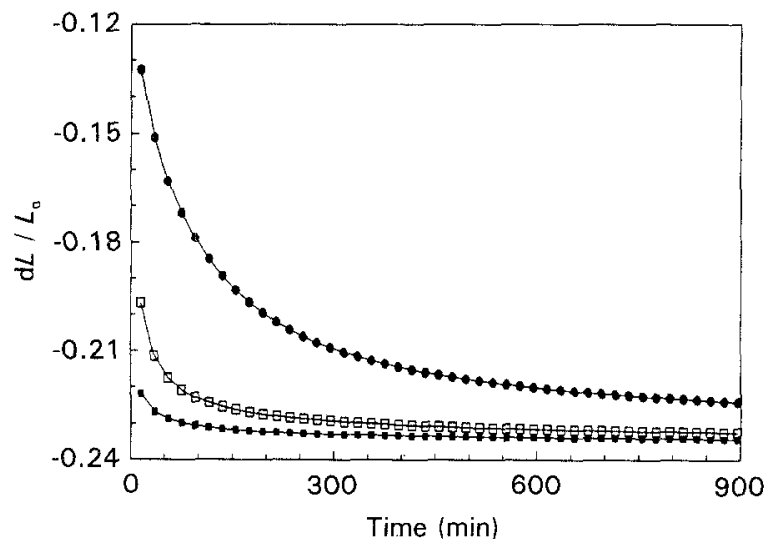

Figure 8 Relative shrinkage as a function of time during isothermal sintering at $1160^{\circ} \mathrm{C}$ of $(\bullet)$ pure and iron-doped ZY5(3): ( $\left.\square\right)$ $0.6 \mathrm{~mol} \%,(\square) 1.2 \mathrm{~mol} \% \mathrm{FeO}_{1.5}$

TABLE IV Grain sizes after non-isothermal $\left(1460^{\circ} \mathrm{C} / 0 \mathrm{~h}\right)$ and isothermal sintering $\left(1160^{\circ} \mathrm{C} / 15 \mathrm{~h}\right)$ of pure and iron-doped $\mathrm{ZY} 5(3)$

\begin{tabular}{lll}
\hline Composition & \multicolumn{2}{l}{ Grain size $(\mu \mathrm{m})$} \\
\cline { 2 - 3 } & $1460^{\circ} \mathrm{C} / 0 \mathrm{~h}$ & $1160^{\circ} \mathrm{C} / 15 \mathrm{~h}$ \\
\hline ZY5 & 0.52 & 0.19 \\
ZY5-0.6 Fe & 0.58 & 0.18 \\
ZY5-1.2 Fe & 0.57 & $0.55^{\mathrm{a}}$ \\
\hline
\end{tabular}

${ }^{a}$ Including discontinuous grains.
$1.2 \mathrm{~mol} \%$ doped material after sintering at $1160^{\circ} \mathrm{C}$ is shown in Fig. 9. While the grain size is very uniform in undoped and $0.6 \mathrm{~mol} \%$ doped $\mathrm{ZY} 5$, the grain size is very non-uniform for $1.2 \mathrm{~mol} \% \mathrm{FeO}_{1.5}$. The microstructure in Fig. 9 shows that discontinuous grain growth takes place in the $1.2 \mathrm{~mol} \%$ doped material, making it unsuitable for superplastic deformation. Moreover, severe fracturing occurred frequently during cooling of this material after different sintering schedules, which was not the result of the tetragonalto-monoclinic phase transformation, because in all iron-doped materials only diffraction peaks of the tetragonal phase could be detected.

\subsubsection{High-temperature compression}

Strain rates as a function of applied stress at $1200^{\circ} \mathrm{C}$ are shown in Fig. 10 for ZY5(2) undoped and doped with $0.5 \mathrm{~mol} \% \quad \mathrm{FeO}_{1.5}$. The grain size equals $\sim 0.15 \mu \mathrm{m}$ for both materials (sintered at $1150^{\circ} \mathrm{C}$ ). The strain rates of a commercially available (Tosoh Co., Japan) Y-TZP material (grain size $0.40 \mu \mathrm{m}$ ) are also shown in this figure for comparison. This material (codename TS2/1) has been tested by Nauer and Carry [26] at $1350^{\circ} \mathrm{C}$ and the strain rates were recalculated to $1200^{\circ} \mathrm{C}$ using $590 \mathrm{~kJ} \mathrm{~mol}^{-1}$ for the creep activation energy, as determined by these authors. The strain rate shows a similar stress dependence in all three materials. Strain rates of ZY5(2) are increased by a factor 30 compared to the commercial TS2/1 material, while addition of $0.5 \mathrm{~mol} \% \mathrm{FeO}_{1.5}$, leads to a further increase by a factor of $4-6$ for the ZY 5(2) material. For stresses above $20 \mathrm{MPa}$, strain rates larger than $10^{-4} \mathrm{~s}^{-1}$ are observed with the iron-doped material.

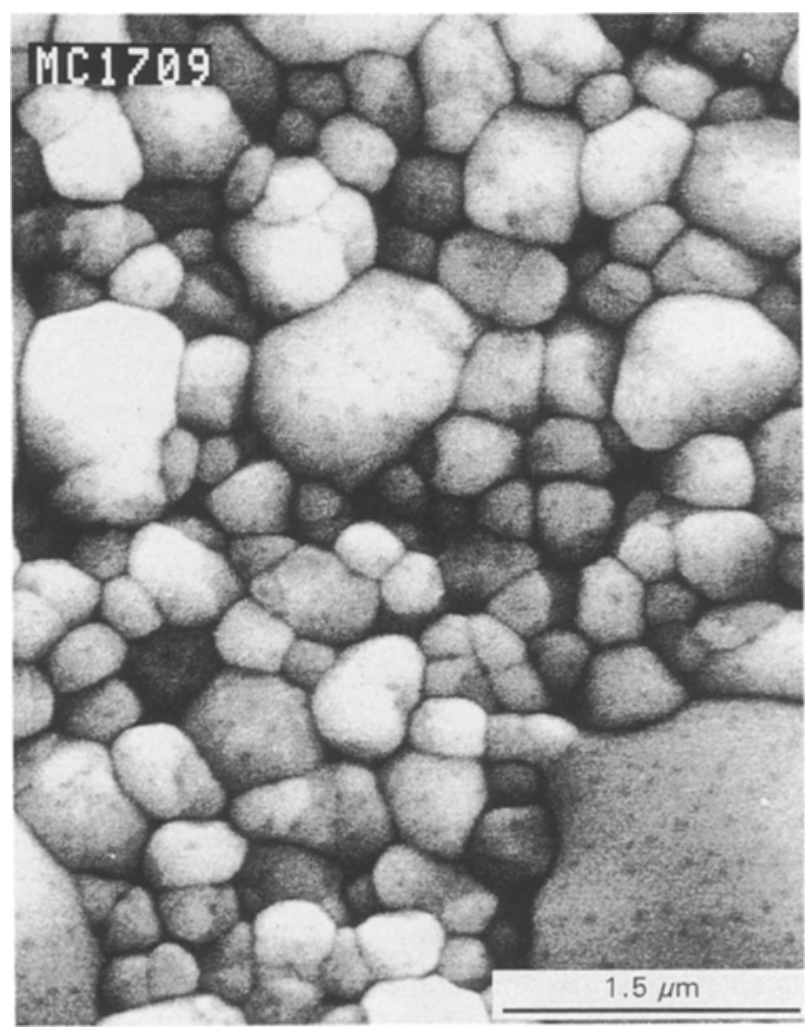

Figure 9 Microstructure of $1.2 \mathrm{~mol} \% \mathrm{FeO}_{1.5}$ doped ZY5(3) after isothermal sintering at $1160^{\circ} \mathrm{C}(15 \mathrm{~h})$. 


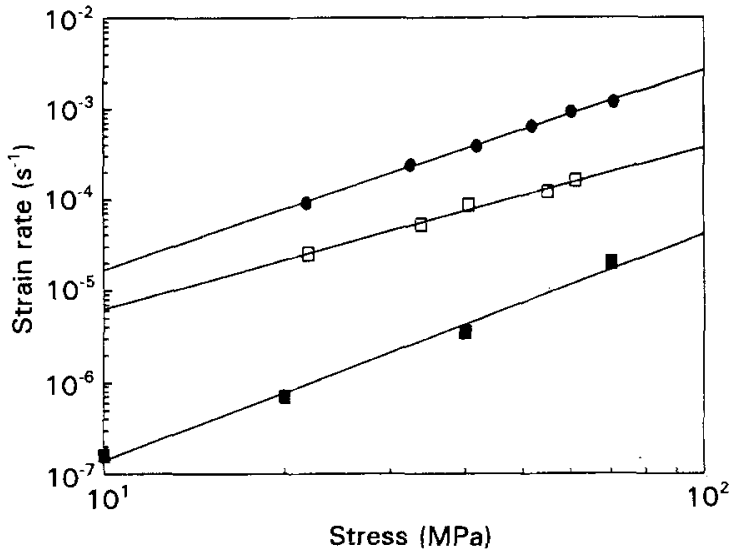

Figure 10 Strain rate as a function of applied stress during compression at $1200^{\circ} \mathrm{C}$ of $(\square)$ pure $\mathrm{ZY5}(2)$, (O) $0.5 \mathrm{~mol} \% \mathrm{FeO}_{1.5}$ doped ZY5(2) and ( $\mathbf{\square})$ a commercial 2Y-TZP material (code TS2/1 [26]).

The creep behaviour of the pure and iron-doped ZY5 materials is described in more detail elsewhere [27].

\section{Discussion}

\section{1. $\mathrm{Bi}_{2} \mathrm{O}_{3}$-doped TZP}

The addition of $1-2 \mathrm{~mol} \% \mathrm{Bi}_{2} \mathrm{O}_{3}$ has been shown to lead to a strong enhancement of densification rates of both ZY5 and ZCe12. This can be explained in terms of a liquid-phase sintering mechanism operating in the $\mathrm{Bi}_{2} \mathrm{O}_{3}$-doped materials. Liquid-phase sintering can be divided into three stages [28-30]: (1) an initial stage, in which the liquid phase is being formed and densification takes place by particle rearrangement under the influence of capillary pressures, (2) an intermediate stage, where solution-reprecipitation leads to further densification, and (3) a final stage, where a solid skeleton forms and densification slows down drastically. The latter phenomenon is only important if large volume fractions of a liquid phase are present. The volume fractions liquid, $V_{\text {liq }}$, in the $\mathrm{Bi}_{2} \mathrm{O}_{3}$-doped materials under investigation equal approximately $3 \%-6 \%$ (calculated from $V_{\text {liq }}=V_{\mathrm{s}}+0.1 V_{\mathrm{s}}$, where $V_{\mathrm{s}}$ is the volume fraction of solid $\mathrm{Bi}_{2} \mathrm{O}_{3}$ and $0.1 V_{\mathrm{s}}$ the volume increase upon melting) and therefore rearrangement and solution-reprecipitation are the most important steps that need to be considered here. The linear shrinkage induced by particle rearrangement is usually assumed to be directly proportional to the volume fraction liquid [28]. It can be estimated that this (linear) shrinkage equals a maximum $11 \%$ for a 6 vol \% liquid containing material with a green density of $47 \%$ (assuming that the relative density increases from $47 \%$ as observed in the green state to $65 \%$, corresponding with the maximum density of a random close-packed three-dimensional array of spheres). This rearrangement is promoted by high surface tension of the liquid, low interparticle friction, small particle size and some solubility of the solid in the liquid [30]. Particle rearrangement will certainly take place in the systems investigated here, but to what extent is not clear. The solution-reprecipitation step is still responsible for a large part of the densification in the $\mathrm{Bi}_{2} \mathrm{O}_{3}$-doped TZPs, because total linear shrinkages exceed $20 \%$.

The presence of $\mathrm{Bi}_{2} \mathrm{O}_{3}$ in the investigated TZPs during sintering led to enhanced grain growth. The increase in grain size was, however, insufficient to account for the observed destabilization of the $t$-phase. This destabilization can possibly be explained by the formation of $\mathrm{Bi}_{2} \mathrm{O}_{3}-\mathrm{Y}_{2} \mathrm{O}_{3}$ or $\mathrm{Bi}_{2} \mathrm{O}_{3}-\mathrm{CeO}_{2}$ liquids: the dissolution of yttria or ceria into this liquid will lead to a strong decrease of the thermodynamic stability of the t-phase. The published binary phase diagrams [31] show that these liquids will form above $800-900^{\circ} \mathrm{C}$. These liquidus temperatures coincide with the onset of sintering in the $\mathrm{Bi}_{2} \mathrm{O}_{3}$-doped TZPs during the non-isothermal runs. (Diffraction peaks of $\mathrm{Bi}_{2} \mathrm{O}_{3}$ were no longer detected above $800^{\circ} \mathrm{C}$ in $2 \mathrm{~mol} \% \mathrm{Bi}_{2} \mathrm{O}_{3}$ doped ZY5.) During isothermal sintering at $950-1050^{\circ} \mathrm{C}$, unidentified crystalline phases are forming; it is reasonable to assume that these consist of $\mathrm{Bi}_{2} \mathrm{O}_{3}-\mathrm{Y}_{2} \mathrm{O}_{3} / \mathrm{CeO}_{2}\left(-\mathrm{ZrO}_{2}\right)$ solid solutions leading to a further destabilization of the $\mathrm{t}$-phase if yttrium or cerium have a larger solubility in these phases than zirconium.

Because of the large degree of transformation to the monoclinic phase after free sintering, the deformation behaviour of $\mathrm{Bi}_{2} \mathrm{O}_{3}$-doped Y-TZP has not been investigated.

\section{2. $\mathrm{Fe}_{2} \mathrm{O}_{3}$-doped $\mathrm{Y}$-TZP}

\subsubsection{Adsorption of $\mathrm{Fe}(A c A c)_{3}$ on to zirconia} The adsorption of acetylacetonates on to the surfaces of metaloxides takes place by reaction of hydroxyl groups with the AcAc group as has been shown by van Hengstum et al. [32] according to the reaction

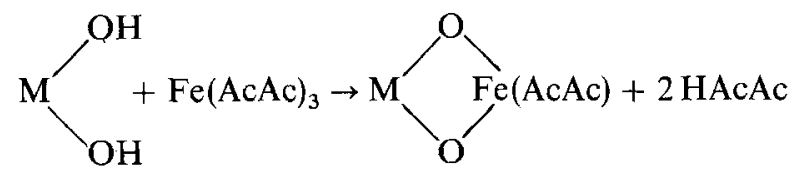

This process produces two HAcAc molecules, which can also adsorb on to the oxide surface. Furthermore, using ethanol as a solvent will lead to the adsorption of ethoxy groups on the surface of zirconia [33]. The adsorption of acetylacetone and ethanol inhibits further adsorption of the metal acetylacetonate. A fractional monolayer coverage of only 0.34 by $\mathrm{Fe}(\mathrm{AcAc})_{3}$ has been found after $72 \mathrm{~h}$ adsorption at $20^{\circ} \mathrm{C}$, corresponding with a $1.2 \mathrm{~mol} \% \mathrm{FeO}_{1.5}$ dopant level for the used ZY5 powder batch. (It should be noted that the starting concentration of $\mathrm{Fe}(\mathrm{AcAc})_{3}$ in solution during adsorption corresponds with six times the monolayer capacity of the $10 \mathrm{~g} \mathrm{ZY5(3)} \mathrm{powder.)}$

A concentration of $0.6 \mathrm{~mol} \% \mathrm{FeO}_{1.5}$ can be adequately added to the high surface area $\left(>96 \mathrm{~m}^{2} \mathrm{~g}^{-1}\right)$ powders used here via the batch-acetylacetonate method, even though the coverages in terms of fractions of a monolayer are low $(0.15$ after $24 \mathrm{~h})$. However, for powders with much lower surface areas $\left(<50 \mathrm{~m}^{2} \mathrm{~g}^{-1}\right)$ the monolayer coverage should exceed the maximum value observed here $(0.34)$ to reach the 
required $0.6 \mathrm{~mol} \%$ concentrations. This requires a modification of the doping method used.

Adsorption of metal acetylacetonates $\mathrm{M}(\mathrm{AcAc})_{n}$ on oxides has been intensively studied to prepare supported oxidic catalysts $[20,32,34]$. From these data two main possibilities emerge to increase the monolayer coverage: (1) to use an apolar solvent such as toluene, which does not adsorb readily on the oxide surface, or (2) to remove the reaction products (HAcAc) together with the unused reactant by carrying out continuous adsorption experiments, where a fresh solution of $\mathrm{M}(\mathrm{AcAc})_{n}$ is led continuously over the adsorbent until the concentration at the inlet and outlet are identical. The last possibility has the drawback that large quantities of solvent and $\mathrm{M}(\mathrm{AcAc})_{n}$ are needed. A less sophisticated method, which does not yield monolayers, but gives a satisfactory dispersion is wet impregnation, where the solvent is removed after adsorption by evaporation $[13,16]$.

\subsubsection{Solid solution formation}

It has furthermore been observed (Section 3.2.2) that the unit-cell volume of the tetragonal phase (after a heat treatment at $1200^{\circ} \mathrm{C}$ ) increases slightly when adding $0.6 \mathrm{~mol} \% \mathrm{Fe}^{3+}$. This is in agreement with the results obtained by Karas et al. [35] with $0.5 \mathrm{~mol} \%$ iron-doped 3Y-TZP. The ionic radii of $\mathrm{Zr}^{4+}$ and $\mathrm{Fe}^{3+}$ (in eight-fold coordination) are, respectively, 0.084 and $0.078 \mathrm{~nm}$ [36]. The increase in unit-cell volume by incorporation of the smaller $\mathrm{Fe}^{3+}$ ions indicates an interstitial rather than a substitutional solid solution formation mechanism

$$
2 \mathrm{Fe}_{2} \mathrm{O}_{3} \rightarrow 4 \mathrm{Fe}_{\mathrm{i}}^{\prime \cdot}+3 \mathrm{~V}_{\mathrm{zr}}^{\prime \prime \prime}+6 \mathrm{O}_{\mathrm{o}}
$$

Karas et al. observed that for higher iron concentrations $(1-2 \mathrm{~mol} \%)$ the unit-cell volume decreases again. This suggests that up to $0.6 \mathrm{~mol} \% \mathrm{Fe}^{3+}$ can be incorporated interstitially, while at higher concentrations iron substitutes for zirconium. Verkerk et al. [13] observed a decrease of the unit-cell volume of cubic $\mathrm{ZrO}_{2}-\mathrm{Y}_{2} \mathrm{O}_{3}$ with $\mathrm{Fe}_{2} \mathrm{O}_{3}$-doping (0.5-2 mol \%) after sintering at $1200{ }^{\circ} \mathrm{C}$, indicating a substitutional solid solution formation mechanism.

The interstitial incorporation of trivalent iron in zirconia has been clearly demonstrated by Hoffmann and Fischer [37]. They found that in $2-9 \mathrm{~mol} \%$ $\mathrm{Fe}_{2} \mathrm{O}_{3}$-doped cubic $\mathrm{ZrO}_{2}-\mathrm{CaO} 30 \%-35 \%$ of the iron atoms were at interstitial positions.

\subsubsection{Enhancement of sintering and creep by $\mathrm{Fe}_{2} \mathrm{O}_{3}$ additions}

Chen and Xue [15] performed a survey of the enhancing effect of transition metal oxides of the fourth row on sintering and creep rates of 2Y-TZP. They argued that the addition of transition metals could lead to a lowering of the eutectic point which is situated at $1350^{\circ} \mathrm{C}$ in the $\mathrm{Y}_{2} \mathrm{O}_{3}-\mathrm{Al}_{2} \mathrm{O}_{3}-\mathrm{SiO}_{2}$ (aluminium and silicon are present as impurities in all zirconia ceramics) ternary phase diagram. This would allow sintering and creep to take place at lower temperatures in Y-TZP doped with transition metal oxides.
However, it has been observed [38] that an amorphous silicate phase is already present at the grain boundaries as a thin ( $\leq 1 \mathrm{~nm}$ ) film in the Y-TZP ceramics studied here after sintering at $1150^{\circ} \mathrm{C}$, i.e. $200^{\circ} \mathrm{C}$ below the reported eutectic temperature. This film is thus already liquid-like at $1150^{\circ} \mathrm{C}$ and any additional effect of iron on sintering and creep of these materials is therefore not as straightforward as suggested by Chen and Xue. Iron doping might, however, cause an increase in the solubility of zirconium into the silicate film, which would lead to an increased diffusion flux of zirconium through it and thus promote densification and creep. Alternatively, iron doping could lead to an increased volume fraction of the liquid phase, which would favour rearrangement processes (see Section 4.1) during sintering, resulting in higher densification rates.

The enhancement of creep rates of Y-TZP by small $(0.6 \mathrm{~mol} \%)$ additions of $\mathrm{FeO}_{1.5}$ observed here, has also been reported by Karas et al. for 3Y-TZP (grain size $0.2 \mu \mathrm{m}$ ). Their strain rates are, however, more than two orders of magnitude lower than observed for the materials in this investigation. A mechanistic study of creep of undoped and iron-doped Y-TZP is presented elsewhere [27].

\section{Conclusions}

1. Addition of $1-2 \mathrm{~mol} \% \mathrm{Bi}_{2} \mathrm{O}_{3}$ leads to a strong enhancement of sintering of both Y-TZP and Ce-TZP. The sintering temperature of these materials can be lowered from $1150^{\circ} \mathrm{C}$ to $1050^{\circ} \mathrm{C}$ or $1000^{\circ} \mathrm{C}$ for, respectively, Y-TZP and Ce-TZP.

2. Concentrations of $1-2 \mathrm{~mol} \% \mathrm{Bi}_{2} \mathrm{O}_{3}$ cause a strong transformation of the tetragonal to the monoclinic phase. The extent of transformation depends on the followed sintering schedule and the stabilizer (yttrium, cerium) type. Isothermal experiments at $950-1050^{\circ} \mathrm{C}$ lead to nucleation of unidentified second phases.

3. Addition of $0.6-1.2 \mathrm{~mol} \% \mathrm{FeO}_{1.5}$ to Y-TZP enhances densification significantly. Grain growth is unaffected by adding $0.6 \mathrm{~mol} \%$ iron, but $1.2 \mathrm{~mol} \%$ $\mathrm{FeO}_{1.5}$ induces discontinuous grain growth during isothermal sintering at $1160^{\circ} \mathrm{C}$.

4. Addition of $0.6 \mathrm{~mol}^{\%} \mathrm{FeO}_{1.5}$ to Y-TZP leads to an enhancement of creep rates by a factor of 4-6. Superplastic forming under $70 \mathrm{MPa}$ with strain rates of $10^{-3} \mathrm{~s}^{-1}$ is possible with this material.

5. Diffusion through the intergranular amorphous film is most probably the dominant diffusion path. The presence of iron might enhance the solubility of zirconium in it, enhancing the diffusion flux of $\mathrm{Zr}^{4+}$ through this film. Alternatively, iron doping could increase the volume fraction of liquid phase at the processing temperatures. Both processes would lead to an increase of densification and creep rates, as has been observed.

\section{Acknowledgements}

Akzo Chemicals is gratefully acknowledged for financial support of this investigation. The authors thank 
René Olde Scholtenhuis for his assistance with experimental work, Marc Smithers for SEM observations, Jaap Boeijsma for XRD measurements, Dr George van de Velde for assistance with determining unit-cell parameters, and Dr Gerard Theunissen for synthesis of the ZCe12 powder batch.

\section{References}

1. F. WAKAI, S. SAKAGUCHI and Y. MATSUNO, Adv. Ceram. Mater. 1 (1986) 259.

2. T. G. NIEH and J. WADSWORTH, in "Ceramics Today Tomorrow's Ceramics", edited by P. Vincenzini (Elsevier Science, Amsterdam, 1991) p. 1527.

3. C. CARRY and A. MOCELLIN, in "High Tech Ceramics", edited by P. Vincenzini (Elsevier Science, Amsterdam, 1987) p. 1043.

4. B. KELLETT, J. Mater. Res. 5 (1990) 2165.

5. X. WU and I-W. CHEN, J. Am. Ceram. Soc. 73 (1990) 746.

6. J. WITTENAUER, T. G. NIEH and J. WADSWORTH, Scripta Metall. Mater. 26 (1992) 551.

7. M. M. R. BOUTZ, A. J. A. WINNUBST and A. J. BURGGRAAF, Mater. Res. Bull. 29 (1994) 31.

8. G. S. A. M. THEUNISSEN, A. J. A. WINNUBST and A. J. BURGGRAAF, J. Eur. Ceram. Soc. 11 (1993) 315

9. P. DESCAMPS, J. TIRLOCQ, F. CAMBIER and F. W A K A I, Silicates Ind. 3-4 (1991) 47.

10. C. HWANG and I-W. CHEN, J. Am. Ceram. Soc. 73 (1990) 1626.

11. H. LIANG, T. E. FISCHER, M. NAUER and C. CARRY, ibid. 76 (1993) 325.

12. K. KEIZER, A. J. BURGGRAAF and G. DE WITH, J. Mater. Sci. 17 (1982) 1095.

13. M. J. VERKERK, A. J..A. WINNUBST and A. J. BURGGRAAF, ibid. 17 (1982) 3113

14. D. J. GREEN, R. H. J. HANNINK and M. V. SWAIN, "Transformation toughening of ceramics" (CRC Press, Boca Raton, FL, 1989).

15. I-W. CHEN and L. A. XUE, J. Am. Ceram. Soc. 73 (1990) 2585.

16. R. H. G. KIMINA MI, J. Mater. Sci. Lett. 9 (1990) 373.

17. K. HABERKO, Ceram. Int. 5 (1979) 148.

18. M. A. C. G. VAN DE GRAAF and A. J. BURGGRAAF, in "Advances in Ceramics", Vol. 12, "Science and Technology of Zirconia II", edited by N. Claussen, M. Rühle and A. H. Heuer (American Ceramic Society, Columbus, OH, 1984) p. 744.
19. W. F. M. GROOT ZEVERT, A. J. A. WINNUBST, G. S. A M. THEUNISSEN and A. J. BURGGRAAF, J. Mater. Sci. 25 (1990) 3449.

20. J. G. VAN OMMEN, K. HOVING, H. BOSCH and P. J. GELlings, Z. Phys. Chem. N.F. 134 (1983) 99.

21. H. TORAYA, M. YOSHIMURA and S. SOMIYA, J. Am. Ceram. Soc. 67 (1984) C119.

22. M. M. R, BOUTZ, Thesis, University of Twente (1993).

23. A. J. A. WINNUBST, P. J. M. KROOT and A. J. BURGGRAAF, J. Phys. Chem. Solids 44 (1983) 955.

24. R. B. ROOF, Acta Crystallogr. 9 (1956) 781.

25. A. E. HUGHES and S. P. S. BADWAL, Solid State Ionics 46 (1991) 265.

26. M. NAUER and C. CARRY, Scripta. Metall. Mater. 24 (1990) 1459.

27. M. M. R. BOUTZ, A. J. A. WINNUBST, A. J. BURGGRAAF, M. NAUER and C. CARRY, J. Eur. Ceram. Soc. 13 (1994) 103

28. W. D. KINGERY, in "Kinetics of high temperature processes", edited by W. D. Kingery (Wiley, New York, 1959) p. 187.

29. TH. COURTNEY, Met. Trans. 15A (1984) 1065.

30. R. M. GERMAN, "Liquid phase sintering" (Plenum Press, New York, 1985).

31. G. SMITH, (ed.), "Phase Diagrams for Ceramist", Vol. IV (American Ceramic Society, Columbus, OH, 1981) pp. 118, 128.

32. A. J. VAN HENGSTUM, J. G. VAN OMMEN, H. BOSCH and P. J. GELlingS, Appl. Catal. 5 (1983) 207.

33. M. S. KALISZEWSK I and A. H. HEUER, J. Am. Ceram. Soc. 73 (1990) 1504

34. J. G. VAN OMMEN, H. BOSCH, P. J. GELLINGS and J. R. H. ROSS, in "Preparation of Catalysts IV", edited by $B$. Delmon, P. Grange, P. A. Jacobs and G. Porcelet (Elsevier Science, Amsterdam, 1987) p. 151.

35. A. KARAS, R. SOSSEN and W. R. CANNON, Presentation (3-JV-90) at the "92nd Annual Meeting of the American Ceramic Society", Dallas, Texas, 22-26 April (1990).

36. R. D. SHANNON, Acta Crystallogr. A32 (1976) 751.

37. A. HOFFMANN and W. A. FISCHER, Z. Phys. Chem. NF 17 (1958) 30.

38. M. M. R. BOUTZ, R. J. M. OLDE SCHOLTENHUIS, A. J A. WINNUBST and A. J. BURGGRAAF, in "Nanoceramics", British Ceramic Proceedings Series Vol. 51, edited by R. Freer (Institute of Materials, London, 1993) pp. 75-86.

Received 11 August 1993

and accepted 21 March 1994 